\title{
Optimization of Electroporation for Transfection of Human Fibroblast Cell Lines with Origin-Defective SV40 DNA: Development of Human Transformed Fibroblast Cell Lines with Mucopolysaccharidoses (I VII)
}

\author{
Hiroyuki Okamoto' ${ }^{1}$ Kazuo Sukegawa, Shunji Tomatsu, Yasuyuki Suzuki and Tadao Orii \\ Department of Pediatrics, Gifu University School of Medicine, Gifu 500, Japan
}

Key words: Electric transfection/SV40/Immortalization Human fibroblasts/Mucopolysaccharidoses

\begin{abstract}
$A B S T R A C T$. To simplify the process of transfection of human fibroblasts and to acquire a suitable number of transformants, we investigated experimental conditions of electric pulse-induced transfection of human fibroblasts using origin-defective simian virus 40 DNA (SV40 (ori-) DNA). Voltage, pulse duration, number of pulses and the concentration of SV40 (ori-) DNA led to the formation of 10 to 30 foci $/ 25 \mathrm{~cm}^{2} 6$ weeks after transfection, using 2 to $3 \times 10^{6}$ cells and a square wave pulse generator. Optimal condition was determined to be 2 or 3 pulses at a voltage of 1500 to $2000 \mathrm{~V} / 0.4 \mathrm{~cm}$ with $30 \mu \mathrm{sec}$ pulse width, using $2 \mu \mathrm{g}$ of linearized SV40 (ori-) DNA. With this approach we developed human transformed fibroblasts cell lines with all types of mucopolysaccharidoses. The transformed fibroblasts grew rapidly and the saturation density exceeded that of the parental cells. All the transformed cell clones expressed $T$ antigen, and deficiency in specific enzymes was conserved. A point mutation which occurred in the human $\beta$-glucuronidase gene in a patient with mucopolysaccharidosis type VII was also conserved.
\end{abstract}

In studying molecular and biochemical aspects of genetic diseases, one of the major obstacles is that cultured fibroblasts have a finite life-span (12) and grow slowly. It is necessary to develop immortal cell lines with rapid growth while conserving the original genetic defects. Immortalization of fibroblasts can be achieved by transfecting with origin-defective simian virus 40 DNA (SV40 (ori-) DNA) $(4,6,7,9,15,23)$. Methods widely used for transfection of SV40 (ori-) DNA into human fibroblast are calcium phosphate co-precipitation $(21,29)$ and DEAE-dextran procedures (16). However, these methods are laborious and inefficient, several kinds of reagents are needed, the $\mathrm{pH}$ must be regulated and the cells must be treated with great care after the transfection.

Electric transfection requires only a pulse generator with no special chemical reagent and therefore overcomes the disadvantages of traditional methods $(1,2$, 17, 24). However, the use of electric transfection with SV40 (ori-) DNA has been complicated by the lack of sufficient information.

Efficiency of electric transfection depends on a number of factors, including construction, form and concen-

\footnotetext{
1 To whom correspondence should be addressed.

Abbreviations: SV40 (ori-) DNA, origin-defective simian virus 40 DNA; MPS, Mucopolysaccharidoses; PBS, phosphate-buffered saline; MEM, Eagle's minimal essential medium; FCS, fetal calf serum.
}

tration of the plasmid DNA, the number of cells, temperature of the samples and electric parameters (1).

Electric parameters include voltage, pulse-duration, the number of pulse and pulse-shape $(1,2,22,31)$. We examined these parameters to form 10 to 30 foci $/ 25 \mathrm{~cm}^{2}$ which are easily distinguished from the background monolayer (26).

Using this approach, we obtained immortalized human fibroblast cell lines with all types of Mucopolysaccharidoses (MPS) $(I \sim V I I)$.

MPS are inherited metabolic diseases characterized by a defect in one of the degradation enzymes for mucopolysaccharides in lysosomes (19). The pathogenesis of these disorders is under investigation at the molecular level (27). We examined enzymatic and molecular events in transformed fibroblasts to ensure that these cell lines could be used as a valid tool for studies on molecular biology of these tissues.

\section{MATERIALS AND METHODS}

Cells. Skin fibroblasts were obtained from control subjects and patients, with informed consent obtained from each subject. These tissues were cultured in Eagle's minimal essential medium (MEM) supplemented with 10\% fetal calf serum (FCS). Cell lines were maintained at $37^{\circ} \mathrm{C}$ in a humidified atmosphere of $5 \% \mathrm{CO}_{2} / 95 \%$ air.

Origin-defective SV40 DNA. SV40 (ori-) DNA (8-16) was 
supplied by the Cancer Research Resources Bank (Tokyo, Japan) $(7,8)$. Plasmid DNA was cut with restriction enzyme Xho I (23) and used for electric transfection.

Electroporation. Electroporation was carried out as described by other workers $(1,22)$ with minor modifications and using CELL FUSION PULSER ESCF-3001 (ESCO Limited, Tokyo, Japan). This is a square wave pulse generator for gene transfer and cell fusion. The parameters (voltage, pulse duration, number of pulses) are all adjustable. Maximum field strength is in the range of $3.0 \mathrm{KV}$, and pulse duration is selectable $(10,20,30,40 \mu \mathrm{sec})$. A disposable plastic cuvette with two aluminum electrodes placed against the opposite walls $(0.4 \mathrm{~cm}$ apart) was used for chambers for electroporation (Rikoh Kagaku Lab., Inc., Tokyo, Japan).

Cells from a logarithmically growing culture were trypsinized, washed once with phosphate-buffered saline (PBS), resuspended at a final concentration of $1 \times 10^{7}$ cells $/ \mathrm{ml}$ and then chilled on ice for 10 minutes. SV40 (ori-) DNA at various concentrations $(0.2 \mu \mathrm{g} / \mathrm{ml}$ to $40 \mu \mathrm{g} / \mathrm{ml})$ was added. Aliquots $(0.25 \mathrm{ml})$ of the mixture were placed in a sterile chamber and pulses at various conditions were generated every 10 seconds. The cell suspensions were left on a clean bench for 5 to 10 minutes then were seeded into $25 \mathrm{~cm}^{2}$ flasks with $6 \mathrm{ml}$ of MEM supplemented with $10 \%$ FCS. The medium was replaced every 4 to 5 days. The number of foci which had grown to a diameter of $0.5 \mathrm{~mm}$ to $1 \mathrm{~mm}$ was counted at the end of the sixth week. Five or six foci were picked up with a micropipette and seeded into $9 \mathrm{~cm}^{2}$ dishes. Twenty-four hours later, the medium was replaced and each culture was transferred into $25 \mathrm{~cm}^{2}$ dishes. The medium was changed every two days, because the transformed cells grew rapidly. The transformants died if replacement of medium was postponed.

Immunoblot analysis of $T$ antigen. SV40 T antigen was visualized by the immunoblot analysis (28), using mouse monoclonal anti-T-Ag IgG (Oncogene Science, Inc., Manhasset, $\mathrm{NY}$ ) and alkaline phosphatase conjugated anti-mouse IgG
(Promega, Madison, WI).

Enzyme assays. Transformed cells were suspended in 20 $\mathrm{mM}$ Tris- $\mathrm{HCl}$ buffer ( $\mathrm{pH} 7.5$ ), sonicated and used for enzyme assays. Lysosomal enzyme activities were measured, using the following substrates. Iduronate-2-sulfatase; $\alpha$-L-iduronic acid 2-sulfate-(1-4)-2,5-anhydro-D-[1- $\left.{ }^{3} \mathrm{H}\right]$ mannitol 6-sulfate (13), sulfamidase (heparan sulfate sulfatase); $\left[\mathrm{N}-{ }^{35} \mathrm{~S}\right]$ heparin (13), $\mathrm{N}$-acetylglucosaminidase; $p$-nitrophenyl $\alpha$-N-acetylglucosaminide (11), N-acetylgalactosamine-6-sulfate sulfatase; $\beta-\mathrm{D}-\mathrm{N}$ acetylgalactosamine 6-sulfate-(1-4)- $\beta$-D-glucuronic acid-(1-3)$\beta$-D-N-acetyl- $\left[{ }^{3} \mathrm{H}\right]$ galactosaminitol 6 -sulfate (25), arylsulfatase $\mathrm{B}$; 4-nitrocatechol sulfate (3), $\alpha$-iduronidase, $\beta$-glucuronidase, $\beta$-galactosidase, $\beta$-hexosaminidase; 4 -metylumbelliferylderivatives (18).

Molecular analysis of the MPS VII transformant. The molecular basis of this enzyme deficiency has been determined by cDNA cloning (27). Briefiy MPS VII transformed fibroblasts were used for extraction of total RNA with guanidium isothiocyanate (5) and poly $\left(\mathrm{A}^{+}\right)$RNA was purified by application onto Hybond-mAP affinity paper from Amersham (30). Oligo $(\mathrm{dT})_{12-17}$ and three different antisense-specific oligo primers were annealed with poly (A) ${ }^{+}$and cDNA were synthesized according to established procedures (10) and ligated into $\mathrm{\lambda gt} 10$ cleaved with $E c o$ RI. The resultant cDNA library was screened by the plaque hybridization method (14), using as a probe the full length of human $\beta$-glucuronidase cDNA (20).

\section{RESULTS AND DISCUSSION}

\section{1) Optimization of electroporation.}

$D N A$ concentration. At conditions of 3 pulses, pulse width $30 \mu \mathrm{sec}, 500 \mathrm{~V} / 0.4 \mathrm{~cm}(1250 \mathrm{~V} / \mathrm{cm})$ and various concentrations of DNA $(0.4 \mu \mathrm{g} / \mathrm{ml}, 2.0 \mu \mathrm{g} / \mathrm{ml}, 4 \mu \mathrm{g} /$ $\mathrm{ml}, 8 \mu \mathrm{g} / \mathrm{ml}, 16 \mu \mathrm{g} / \mathrm{ml}$ and $40 \mu \mathrm{g} / \mathrm{ml})$, the number of foci increased according to the concentration of DNA (Fig. 1-A).
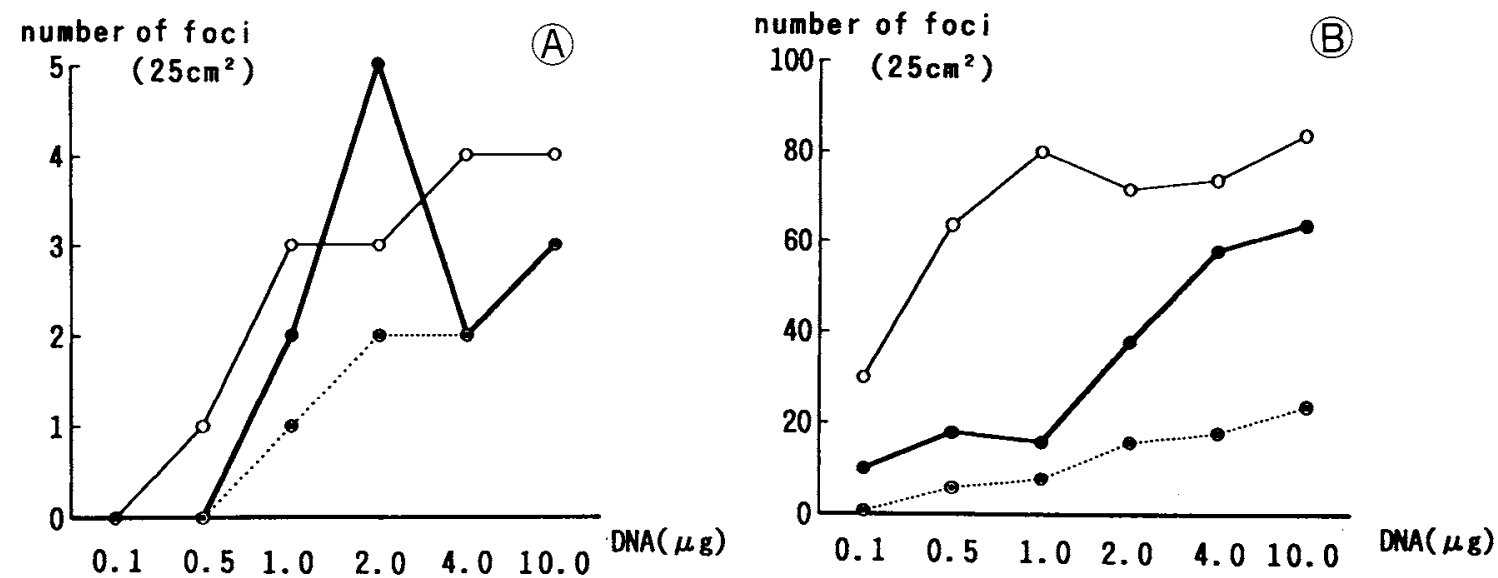

Fig. 1-A. B. The number of foci at various concentrations of DNA: 3 pulses at pulse width $30 \mu \mathrm{sec}$, (A) $500 \mathrm{~V} / 0.4 \mathrm{~cm}$ and (B) $2,000 \mathrm{~V} / 0.4$ $\mathrm{cm} . \longrightarrow$ : control, $\bullet$ MPS I, $0^{---0}$ : MPS VII 

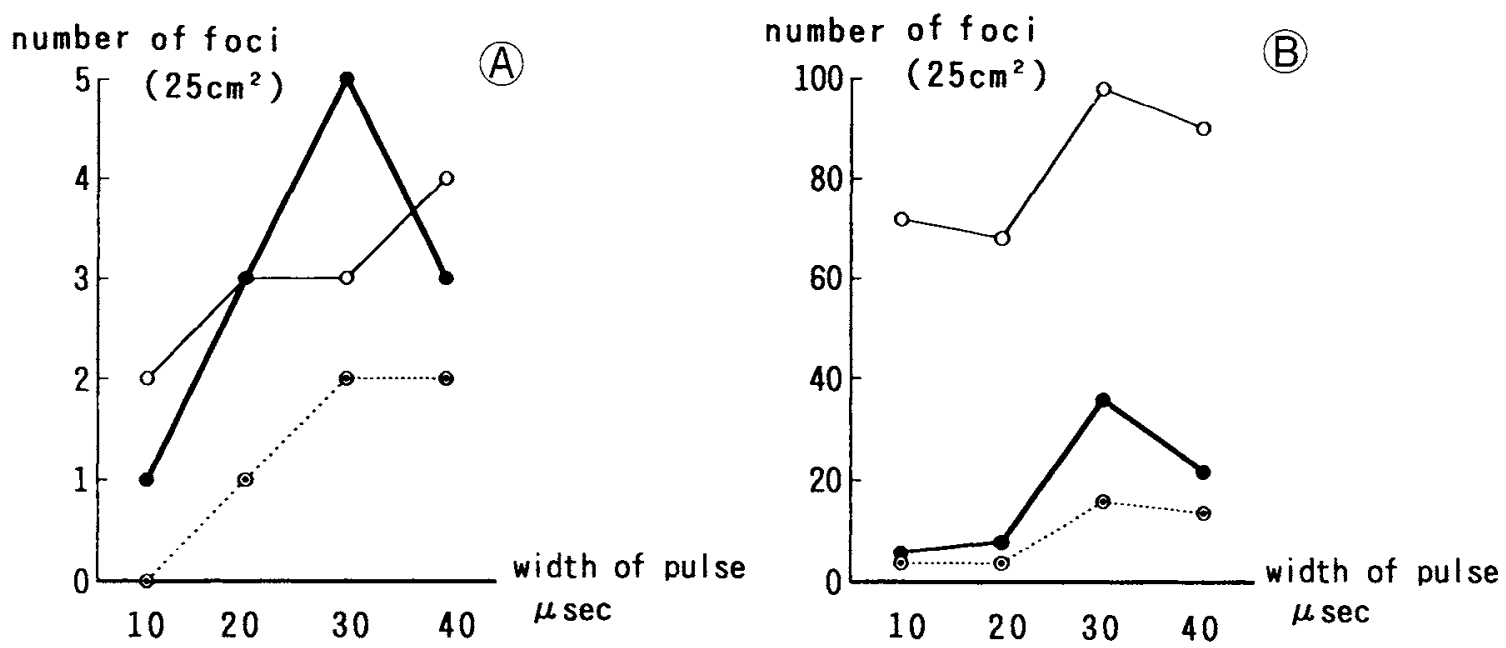

Fig. 2-A. B. The number of foci at various pulse width: 3 pulses, the concentration of DNA $8 \mu \mathrm{g} / \mathrm{ml}$, (A) $500 \mathrm{~V} / 0.4 \mathrm{~cm}$ and (B) $2,000 \mathrm{~V} / 0.4$ $\mathrm{cm}$. $\longrightarrow$ : control, $\bullet-$ : MPS I, $\odot--\infty$ : MPS VII

The number of foci at $2,000 \mathrm{~V} / 0.4 \mathrm{~cm}(5,000 \mathrm{~V} / \mathrm{cm})$ were 4 to 40 times greater than that at $500 \mathrm{~V} / 0.4 \mathrm{~cm}$ (Fig. 1-B). A sufficient number of foci was obtained at a lower concentration of plasmid DNA. There was a marked difference in the number of foci between the cell lines used.

Pulse width. At conditions of 3 pulses, the concentration of DNA $8 \mu \mathrm{g} / \mathrm{ml}, 500 \mathrm{~V} / 0.4 \mathrm{~cm}$ and various pulse width ( $10 \mu \mathrm{sec}, 20 \mu \mathrm{sec}, 30 \mu \mathrm{sec}, 40 \mu \mathrm{sec})$, the number of foci increased according to the pulse width (Fig. 2 -A). At $2000 \mathrm{~V} / 0.4 \mathrm{~cm}$, the number of foci increased 4 to 20 times greater than that at $500 \mathrm{~V} / 0.4 \mathrm{~cm}$ (Fig. 2-B). In the control fibroblasts, there was no significant difference in the number of foci when the pulse width was changed. A 30 to $40 \mu \mathrm{sec}$ pulse width was considered to be adequate to obtain a sufficient number of foci.

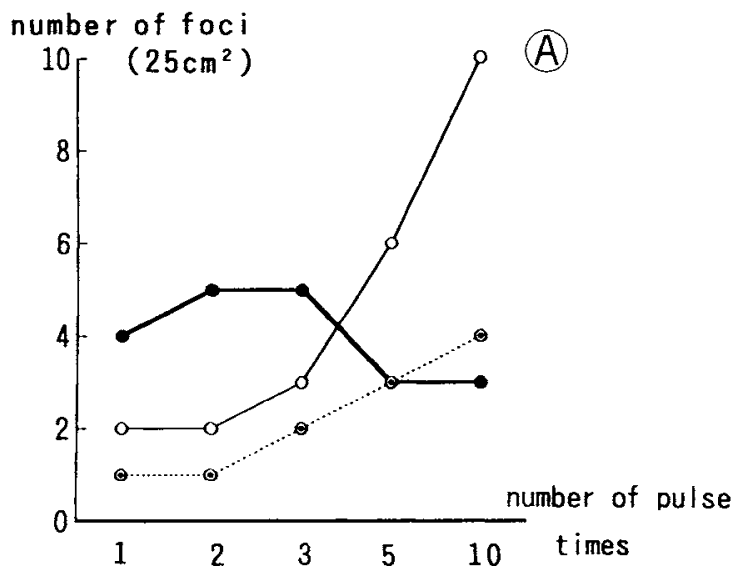

The number of pulses. When the concentration of DNA was $8 \mu \mathrm{g} / \mathrm{ml}$, pulse width $30 \mu \mathrm{sec}, 500 \mathrm{~V} / 0.4 \mathrm{~cm}$ and various number of pulses, the number of foci increased as the number of pulses increased, except in one cell line (Fig. 3-A). The number of foci at 2,000 V/0.4 $\mathrm{cm}$ was one to 40 times greater than that at $500 \mathrm{~V} / 0.4$ cm (Fig. 3-B).

Voltage (Electric field strength). When the DNA concentration was $8 \mu \mathrm{g} / \mathrm{ml}$, pulse width $30 \mu \mathrm{sec}, 3$ pulses and various voltage ( 300 to $3,000 \mathrm{~V} / 0.4 \mathrm{~cm}$ ), the number of foci increased as the field strength increased up to $3,000 \mathrm{~V} / 0.4 \mathrm{~cm}$ in MPS I and MPS VII fibroblasts. In the control cell line, the number of foci increased as the voltage increased up to $2,000 \mathrm{~V} / 0.4 \mathrm{~cm}$ (Fig. 4). Under these conditions, the fibroblasts were not killed by electroporation.

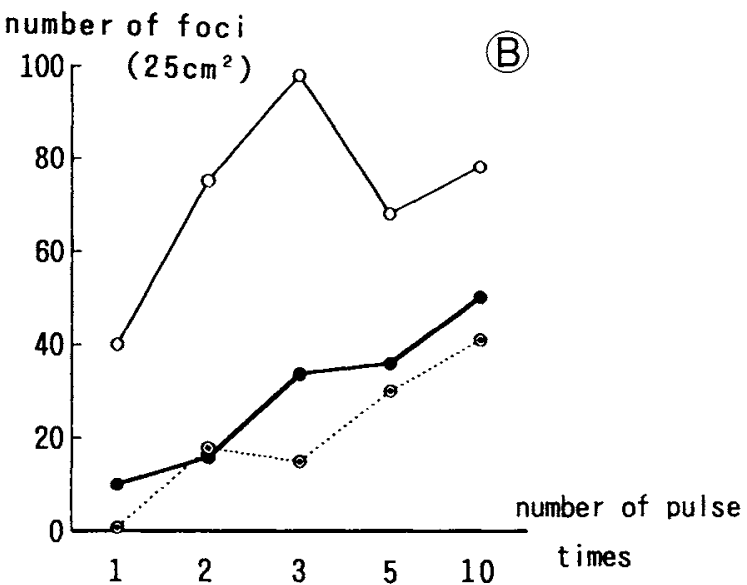

Fig. 3-A. B. The number of foci at various number of pulses: the concentration of DNA $8 \mu \mathrm{g} / \mathrm{ml}$, pulse width $30 \mu \mathrm{sec}$, (A) $500 \mathrm{~V} / 0.4 \mathrm{~cm}$ and (B) 2,000 V/0.4 cm. $\multimap$ : control, $\longrightarrow$ : MPS I, $-\cdots$ : MPS VII 
Thus, the electric field strength was considered to be the most important parameter. At a high voltage $(2,000$ to $3,000 \mathrm{~V} / 0.4 \mathrm{~cm}$ ), too many foci often formed and it was difficult to distinguish them. At a lower voltage (300 to $1,000 \mathrm{~V} / 0.4 \mathrm{~cm}$ ) no focus was formed in some cell lines.

The efficiency of electric transfection also depends on the cell line used; however, we have no explanation for this phenomenon $(1,2)$. The MPS I cell line used in these experiments showed different behavior from the other cell lines in the lower electric field strength (Fig. 1A, 2-A, 3-A). This phenomenon may be brought about by the scanty number of focus in the lower voltage. Other MPS I cell lines did not show a similar behavior (data not shown).

As the optimal condition to form 10 to $30 \mathrm{foci} / 25$ $\mathrm{cm}^{2}$ using 2 to $3 \times 10^{6}$ cells, we chose 2 or 3 pulses at the voltage of 1,500 to $2,000 \mathrm{~V} / 0.4 \mathrm{~cm}(3,750$ to 5,000 $\mathrm{V} / \mathrm{cm}$ ) with a $30 \mu \mathrm{sec}$ pulse width using $2 \mu \mathrm{g}$ of linear-

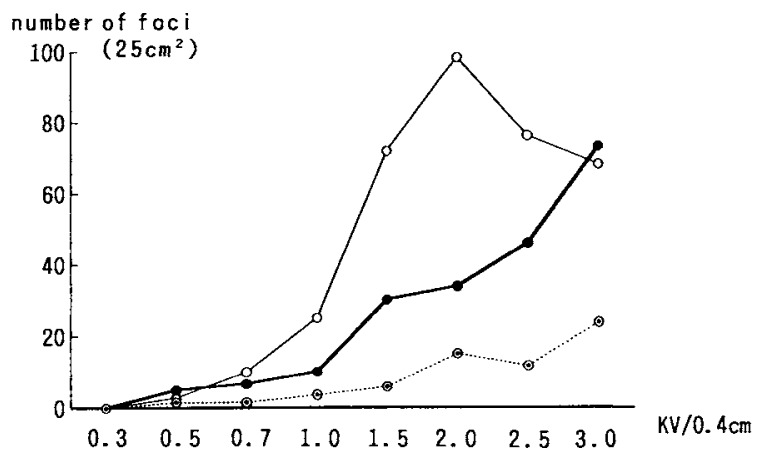

Fig. 4. The number of foci at various field strength: the DNA concentratin $8 \mu \mathrm{g} / \mathrm{ml}$, pulse width $30 \mu \mathrm{sec}$ and 3 pulses. $\bigcirc \mathrm{O}$ : control, $\bullet$ : MPS I, (0-.-@: MPS VII

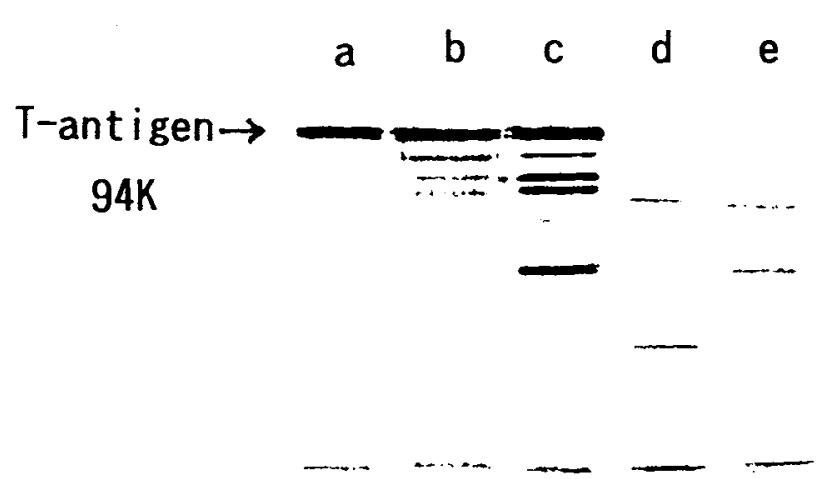

Fig. 5. Immunoblot analysis of large $T$ antigen. Cell extracts were subjected to SDS/polyacrylamide gel electrophoresis and immunoblot analysis using anti-T-Ag IgG and alkaline phosphatase conjugated second antibody. Lane a; MPS I transformant, b; MPS VII transformant, c; control transformant, d; MPS I (untransformed), e; MPS VII (untransformed). In lanes $a, b$, c, a large T-antigen with a molecular mass of $94 \mathrm{kDa}$ was evident. ized SV40 (ori-) DNA. These transformed cells had a doubling time 2 to 3 times faster than that of the untransformed parental cells and the saturation density was $4 \sim 8$ times more than that seen in the parental cells (data not shown).

\section{2) Immunoblot analysis of $T$ antigen in the trans- formed cells.}

$\mathrm{T}$ antigen was detected in extracts from these transformed cells and the size was comparable to that of the purified $\mathrm{T}$ antigen ( $94 \mathrm{kDa}$ ) (Fig. 5).

In the untransformed fibroblasts, $\mathrm{T}$ antigen was not detected. Several bands seen in transformants were considered to be nonspecific due to a long exposure to colour-developing solution.

\section{3) Molecular analysis of MPS VII transformant.}

A point mutation which occurred in the $\beta$-glucuronidase gene in a patient with MPS VII (27) was also conserved in the transformant (Fig. 6). A C to $\mathrm{T}$ transition
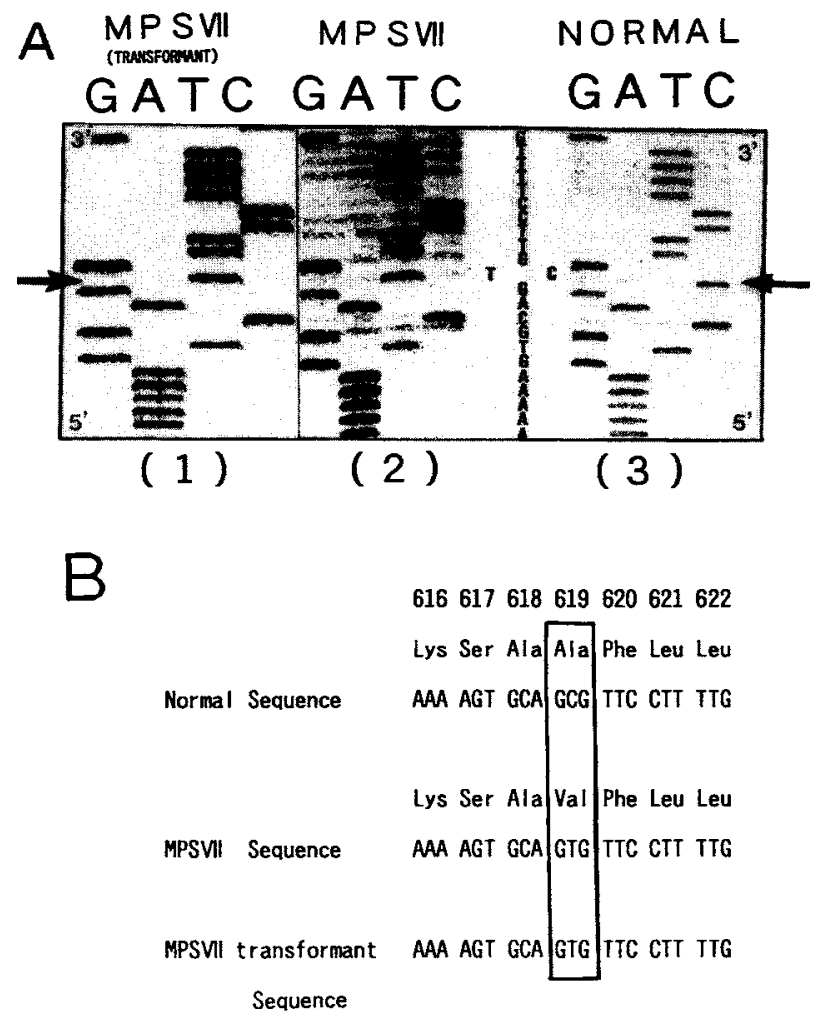

Fig. 6. Sequence analysis of the $\beta$-glucuronidase gene.

(Panel A) The results of sequencing for MPS VII transformant (1) MPS VII (untransformed) (2) and control (untransformed) (3) cDNA are shown around amino acids 616-622. Arrows indicate the site of mutation. The sequence is described with a T (MPS VII and MPS VII transformant) substituted for a $C$ (control).

(Panel B) The nucleotide and corresponding amino acid substitutions are boxed. 
Table I. Activities of lysosomal enzymes after transfection with SV 40 (ori-) DNA. (Mucopolysaccharidoses Type I-VII)

\begin{tabular}{|c|c|c|c|}
\hline MPS I & $\alpha$-iduronidase & $\beta$-galactosidase & $\beta$-hexosaminidase \\
\hline Hurler-1 $(\mathrm{n}=2)$ & 0.3 & 270 & 1696 \\
\hline Hurler-2 $(n=2)$ & 0.3 & 280 & 1412 \\
\hline Scheie $(n=4)$ & 0.4 & 443 & 2598 \\
\hline Control $(n=2)$ & 30.9 & 365 & 2087 \\
\hline MPS II (severe) & iduronate-2 sulfatase & $\beta$-galactosidase & $\beta$-hexosaminidase \\
\hline Hunter-1 $(n=5)$ & 0.3 & 447 & 1828 \\
\hline Hunter-2 $(n=2)$ & n.d & 398 & 3023 \\
\hline Hunter-3 $(n=1)$ & n.d & 352 & 1207 \\
\hline Control $(n=2)$ & 18.6 & 365 & 2087 \\
\hline MPS III & sulfamidase & $\beta$-galactosidase & $\beta$-hexosaminidase \\
\hline Sanfilippo A $(n=2)$ & n.d & 576 & 2679 \\
\hline Control $(n=2)$ & 3.3 & 365 & 2087 \\
\hline MPS III & $\alpha-\mathrm{N}$-acetylglucosaminidase & $\beta$-galactosidase & $\beta$-hexosaminidase \\
\hline Sanfilippo B $(\mathrm{n}=2)$ & 0.1 & 574 & 2529 \\
\hline Control $(n=2)$ & 96 & 365 & 2087 \\
\hline MPS IV (severe) & $\begin{array}{l}\text { N-acetylgalactosamine-6-sulfate } \\
\text { sulfatase }\end{array}$ & $\beta$-galactosidase & $\beta$-hexosaminidase \\
\hline Morquio-1 $(n=6)$ & n.d & 242 & 1217 \\
\hline Morquio-2 $(n=4)$ & 0.3 & 406 & 1916 \\
\hline Control $(n=2)$ & 11.2 & 365 & 2087 \\
\hline MPS VI & arylsulfatase B & $\beta$-galactosidase & $\beta$-hexosaminidase \\
\hline Maroteaux-Lamy-1 $(n=1)$ & 7.2 & 344 & 2419 \\
\hline Maroteaux-Lamy-2 $(n=1)$ & 18.3 & 366 & 1582 \\
\hline Control $(n=2)$ & 294.5 & 365 & 2087 \\
\hline MPS VII & $\beta$-glucuronidase & $\beta$-galactosidase & $\beta$-hexosaminidase \\
\hline$\beta$-glucuronidase deficiency-1 $(\mathrm{n}=7)$ & 0.8 & 345 & 4200 \\
\hline$\beta$-glucuronidase deficiency-2 $(n=2)$ & 0.6 & 137 & 2236 \\
\hline Control $(n=2)$ & 28.9 & 264 & 2733 \\
\hline
\end{tabular}

Values represent mean. Samples number shows their transformed clones.

changed $\mathrm{Ala}^{619}$ to Val in the amplified DNA fragment.

\section{4) Enzyme assays.}

The deficiency of specific lysosomal enzymes was conserved in transformed fibroblasts from the patients (Table I). Other lysosomal enzyme activities were normal and remained unchanged after transformation.

By electric transfection, we could readily establish human transformed fibroblast cell lines with all types of MPS. All transformed cell clones have a higher potential for growth and the deficiency of a specific enzyme was conserved. These cells maintained growth potential for 30 to 40 cell generations, yet immortalization of these cells remains to be determined. These transformants are useful to obtain a large number of cells in a short time. For research on genetic diseases such as en- zyme assay, subcellular fractionation, RNA and DNA extraction, cloning experiments and gene expression, these transformed fibroblasts will serve a purpose.

Acknowledgments. This work was supported in part by Grantsin-Aid for Scientific Research (03265-102, 03557044) from the Ministry of Education, Science and Culture of Japan, and by Grant (2A-6) from National Center of Neurology and Psychiatry (NCNP) of the Ministry of Health and Welfare of Japan.

\section{REFERENCES}

1. Andreason, G.L. and Evans, G.A. (1988). Introduction and expression of DNA molecules in eukaryotic cells by electroporation. BioTechniques., 6: 650-660.

2. Andreason, G.L. and Evans, G.A. (1989). Optimization of electroporation for transfection of mammalian cell lines. Anal. 
Biochem., 180: 269-275.

3. Baum, H., Dodgson, K.S., and Spencer, B. (1959). The assay of arylsulfatases $\mathrm{A}$ and $\mathrm{B}$ in human urine. Clin. Chim. Acta., 4: 453-455.

4. Boast, S., LaMantia, G., Lania, L., and Blasi, F. (1983). High efficiency of replication and expression of foreign genes in SV40-transformed human fibroblasts. The EMBO J., 2: 23272331.

5. Chomczynski, P. and SaCchi, N. (1987). Single-step method of RNA isolation by acid guanidinium thiocyanate-phenol-chloroform extraction. Anal. Biochem., 162: 156-159.

6. Furuya, T., MomoI, T., and Suzuki, Y. (1985). Establishment of human fibroblast cell lines with lysosomal enzyme deficiency by transformation with origin-minus SV40 DNA. J. Inher. Metab., Dis. 8: 143-144.

7. Gluzman, Y., Frisque, R.J., and Sambrook, J. (1980). Origin-defective mutant of SV40. Cold Spring Harbor Symp. Quant. Biol., 44: 293-300.

8. Gluzman, Y., SAMbrook, J.F., and Frisque, R.J. (1980). EXpression of early genes of origin-defective mutants of simian virus 40. Proc. Natl. Acad. Sci. USA., 77: 3898-3902.

9. GluZman, Y. (1981). SV40-transformed simian cells support the replication of early SV40 mutants. Cell, 23: 175-182.

10. Gubler, U. and HoffmaN, B. (1983). A simple and very efficient method for generating cDNA libraries. Gene., 25: 263269.

11. Hall, C.W., Liebaers, I., DiNatale, P., and Neufeld, E.F. (1978). Enzymic diagnosis of the genetic mucopolysaccharide storage disorders. Methods in Enzymol., Vol. L: 447-450.

12. HAYFLICK, L. (1965). The limited in vitro lifetime of human diploid cell strains. Exp. Cell Res., 37: 614-636.

13. Liebaers, I. and NeUfeld, E.F. (1976). Iduronate sulfatase activity in serum, lymphocytes, and fibroblasts-simplified diagnosis of the Hunter syndrome. Pediat. Res., 10: 733-736.

14. Maniatis, T., Fritsch, E.F., and Sambrook, J. (1982). A Laboratory Manual. Cold Spring Harbor Laboratory, Cold Spring Harbor, NY.

15. Mayne, L.V., Priestley, A., James, M.R., and Burke, J.F. (1986). Efficient immortalization and morphological transformation of human fibroblasts by transfection with SV40 DNA linked to a dominant marker. Exp. Cell Res., 162: 530-538.

16. McCutchan, J.H. and Pagano, J.S. (1968). Enhancement of the infectivity of simian virus 40 deoxyribonucleic acid with diethyl-aminoethyl-dextran. $J$. Natl. Cancer Inst., 41: 351-357.

17. Ohtani, K., Nakamura, M., Saito, S., Nagata, K., SugamUra, K., and Hinuma, Y. (1989). Electroporation: application to human lymphoid cell lines for stable introduction of a transactivator gene of human T-cell leukemia virus type I. Nucleic Acids Res., 17: 1589-1604.

18. Oril, T., Minami, R., Sukegawa, K., Sato, S., Tsugawa, S.
Horino, K., MiUra, R., and NAKAO, T. (1972). A new type of mucolipidosis with $\beta$-galactosidase deficiency and glycopeptiduria. Tohoku J. Exp. Med., 107: 303-315.

19. ORII, T, (1986). Screening, enzymatic diagnosis and heterozygote identification of genetic mucopolysaccharidoses. Asian Med. J., 29: 89-99.

20. Oshima, A., Kyle, J.W., Miller, R.D., Hoffman, J.W., Powell, P.P., Grubb, J.H., Sly, W.S., TropaK, M., Guise, K.S., and GRAVEL, R.A. (1987). Cloning, sequencing, and expression of cDNA for human $\beta$-glucuronidase. Proc. Natl. Acad. Sci. USA., 84: 685-689.

21. PARKer, B.A. and StARK, G.R. (1979). Regulation of simian virus 40 transcription: Sensitive analysis of the RNA species present early in infections by virus or viral DNA. J. Virol., 31: 360369

22. Potter, H. (1988). Electroporation in biology: Method, application, and instrumentation. Anal. Biochem., 174: 361-373.

23. Small, M.B., Gluzman, Y., and Ozer, H.L. (1982). Enhanced transformation of human fibroblasts by origin-defective simian virus 40. Nature, 296: 671-672.

24. Stopper, H., Zimmermann, U., and Wecker, E. (1985). High yields of DNA-transfer into mouse L-cells by electropermeabilization. Z. Naturforsch., 40c: 929-932.

25. SukegawA, K. and ORII, T. (1982). Residual activity in fibroblasts from two brothers with the late-onset form of N-acetylgalactosamine-6-sulphate sulphatase deficiency. J. Inher. Metab. Dis. 5: 231-232.

26. Todaro, G.J., Green, H., and Swift, M.R. (1966). Susceptibility of human diploid fibroblast strains to transformation by SV40 virus. Science, 153: 1252-1254.

27. Tomatsu, S., Sukegawa, K., Ikedo, Y., FukUda, S., Yamada, Y., Sasaki, T., Okamoto, H., Kuwabara, T., and Orit, T. (1990). Molecular basis of mucopolysaccharidosis type VII: replacement of $\mathrm{Ala}^{619}$ in $\beta$-glucuronidase with Val. Gene., 89: 283-287.

28. Towbin, H., Staehelin, T., and Gordon, J. (1979). Electrophoretic transfer of proteins from polyacrylamide gels to nitrocellulose sheets: Procedure and some applications. Proc. Natl. Acad. Sci. USA., 76: 4350-4354.

29. Wigler, M., Pellicer, A., Silverstein, S., and Axel, R. (1978). Biochemical transfer of single-copy eucaryotic genes using total cellular DNA as donor. Cell., 14: 725-731.

30. Wreschner, D.H. and Herzberg, M. (1984). A new blotting medium for the simple isolation and identification of highly resolved messenger RNA. Nucleic Acids Res., 12: 1349-1359.

31. XIE, T-D., Sun, L., and Tsong, T.Y. (1990). Study of mechanisms of electric field-induced DNA transfection 1: DNA entry by surface binding and diffusion through membrane pores. Biophys. J., 58: 13-19.

(Received for publication, January 7, 1992

and in revised form, March 4, 1992) 